\title{
Coronavirus infections in hospitalized pediatric patients with acute respiratory tract disease
}

\author{
Monika Jevšnik ${ }^{1 *}$, Tina Uršič ${ }^{1}$, Nina Žigon ${ }^{1}$, Lara Lusa ${ }^{3}$, Uroš Krivec $^{2}$ and Miroslav Petrovec ${ }^{1}$
}

\begin{abstract}
Background: Acute viral respiratory infections are an important cause of morbidity and mortality in humans worldwide. The etiological backgrounds of these infections remain unconfirmed in most clinical cases. The aim of this study was to estimate the prevalence of human coronavirus infections in a series of children hospitalized with symptoms of acute respiratory tract disease in a one-year period in Slovenia.

Methods: The 664 specimens from 592 children under six years of age hospitalized at the University Children's Hospital in Ljubljana were sent for the routine laboratory detection of respiratory viruses. Respiratory viruses were detected with a direct immunofluorescence assay and human coronaviruses were detected with a modified real-time RT-PCR.
\end{abstract}

Results: HCoV RNA was detected in 40 (6\%, 95\% Cl: 4.3\%-8.1\%) of 664 samples. Of these specimens, $21 / 40$ (52.5\%) were identified as species HKU1, $7 / 40(17.5 \%)$ as OC43, $6 / 40(15 \%)$ as $229 \mathrm{E}$, and $6 / 40$ (15\%) as NL63. Infection with $\mathrm{HCoV}$ occurred as a coinfection with one or more other viruses in most samples (70\%). Of the HCoV-positive children, 70.3\% had lower respiratory tract infections.

Conclusion: The results of our study show that HCoV are frequently detected human pathogens, often associated with other respiratory viruses and acute respiratory tract infections in hospitalized children. An association between age and the viral load was found. The highest viral load was detected in children approximately 10 months of age.

Keywords: Hospitalized children, Human coronavirus, Respiratory viral infection

\section{Background}

Acute infections of the respiratory tract are a major cause of morbidity and mortality in humans worldwide and approximately $80 \%$ are caused by viruses $[1,2]$. The viruses most frequently associated with respiratory tract infections include respiratory syncytial virus (RSV), parainfluenza viruses (PIV), influenza viruses (Flu), adenoviruses (AdV), human rhinoviruses (hRV), and enteroviruses, and less commonly, human metapneumovirus (hMPV), human bocavirus ( $\mathrm{HBoV})$, and human coronaviruses $(\mathrm{HCoV})$. Until recently, it was believed that $\mathrm{HCoVs}$ were responsible for the common cold syndrome and were the cause of only mild upper respiratory tract infections (URTIs) [3]. After the SARS epidemic in 2003, it was established that these viruses can also be associated with severe, life-threatening, or even fatal

\footnotetext{
* Correspondence: monika.jevsnik@mf.uni-lj.si

${ }^{1}$ Institute of Microbiology and Immunology, Faculty of Medicine, University of Ljubljana, Zaloška 4, Ljubljana 1000, Slovenia

Full list of author information is available at the end of the article
}

respiratory infections [4]. Stewart at al. have also suggested a possible relationship between $\mathrm{HCoV}$ infections and the development of extrarespiratory symptoms, including some involving the central nervous system [5]. The role of $\mathrm{HCoV}$ in human gastrointestinal infections also awaits more detailed exploration [6,7].

The aim of this study was to estimate the prevalence of $\mathrm{HCoV}$ in a series of hospitalized infants and young children with symptoms of respiratory tract disease at the University Children's Hospital in Ljubljana from June 2007 to May 2008. The main focus of the present study was to detect all four human coronaviruses in hospitalized children. A proportion of the patients included in this study have been partially described in a separate publication [8].

\section{Methods}

\section{Study population}

From June 2007 to May 2008, 897 respiratory specimens from 741 pediatric patients hospitalized at the University 
Children's Hospital in Ljubljana with acute respiratory tract infections (ARTIs), were sent to the laboratory of the Institute of Microbiology and Immunology, Faculty of Medicine, University of Ljubljana, for the routine detection of respiratory viruses. The number of patients included in this study represented virtually all of hospitalized children with diagnosis of viral respiratory tract infection in this period.

Of these, 664 (74\%) respiratory specimens (nasopharyngeal and throat swabs in viral transport medium, tracheal aspirates, bronchoalveolar lavage, or sputum) from 592 preschool children aged from three days to 72 months were included in to further analysis. Each of the 664 samples represented a different hospitalization event, except for one child from whom two different samples were taken and submitted for analysis (nasopharyngeal swab and bronchoalveolar lavage). Remaining $233(26 \%)$ respiratory specimens were collected from 149 children either older than 72 months or were taken during the same hospitalization event. Therefore these specimens were excluded from the further analysis.

Demographic and clinical data were extracted from the children's medical records and were available for 37 $\mathrm{HCoV}$-positive children and $395 \mathrm{HCoV}$-negative children.

The present study was approved by the National Medical Ethics Committee, Ljubljana, Slovenia (no. 60/02/09).

\section{Laboratory investigations}

Total nucleic acids were isolated from $190 \mu \mathrm{L}$ of each respiratory specimen using a total nucleic acid isolation kit on a MagNA Pure Compact instrument (Roche Applied Science, Mannheim, Germany), according to the manufacturer's instructions. An additional $5 \mu \mathrm{L}$ of equine herpesvirus 1 and equine arteritis virus isolates were included in the nucleic acid extraction as internal controls and were detected in separate duplex PCR reactions with other specific targets $[9,10]$.

The specimens were initially tested with direct immunofluorescence assays (DFAs; Oxoid, Cambridge, UK) for RSV, Flu A/B, PIV1-3, and AdV. After the routine detection assays, the remaining samples were stored frozen until their nucleic acid extraction.

All four human coronaviruses (229E, OC43, NL63, and HKU1) were detected with a modified coronavirus consensus real-time RT-PCR assay performed on a StepOne Real-Time PCR System (Applied Biosystems, Foster City, USA) to amplify 85-100-bp fragments of the polymerase $1 \mathrm{~b}$ gene [11]. The real-time RT-PCR assays were performed as one-step reactions (SuperScript III Platinum One-Step Quantitative RT-PCR System; Invitrogen, CA, USA) within a single tube and a final volume of $20 \mu \mathrm{L}$, containing $5 \mu \mathrm{L}$ of RNA and additional $6 \mathrm{mM} \mathrm{MgSO} 4$. The cycling conditions were as follows: $20 \mathrm{~min}$ at $50^{\circ} \mathrm{C}, 2 \mathrm{~min}$ at $95^{\circ} \mathrm{C}$, and 45 cycles of $15 \mathrm{~s}$ at $95^{\circ} \mathrm{C}$ and $45 \mathrm{~s}$ at $60^{\circ} \mathrm{C}$. All samples that were positive in the coronavirus screening assay were analyzed with a subtype-specific assay in which all the coronavirus species were detected separately [11]. All the specimens were also subsequently tested with real-time RT-PCR for the presence of hRV [12], hMPV [13], and HBoV [14] using previously published assays.

The relative quantity of viral RNA was estimated from the $\mathrm{Ct}$ values (cycle threshold; the cycle number at which the real-time fluorescent signal of the amplification target was above the background noise level) of the real-time PCR. A lower $\mathrm{Ct}$ value was interpreted as indicating a higher viral load.

\section{Statistical analysis}

Categorical data are summarized as frequencies (\%) and numerical data as medians (range).

The association between age and $\mathrm{HCoV}$ viral load was assessed with a linear regression model. Restricted cubic splines [15] were used to flexibly model the relationship between $\mathrm{Ct}$ in the $\mathrm{HCoV}$ assays and patient age. The shape of the estimated association is presented graphically [16].

We considered nine clinical characteristics (fever, oxygen support required, cough, rhinorrhea, dyspnea, wheezing, vomiting, location of the respiratory tract infection, and bronchiolitis) and used univariate logistic regression models with Firth's correction to assess the association between $\mathrm{HCoV}$ positivity (covariate) and each clinical characteristic (response variables; these models are indicated as "models (a)" in the Results section). We further defined a three-category variable for the $\mathrm{HCoV}$ results: $\mathrm{HCoV}$ negative, $\mathrm{HCoV}$ positive with monoinfection, and $\mathrm{HCoV}$ positive with coinfection. We fitted an additional set of univariate models using the new variables as the covariates ("models (b)"). Only the first hospitalization for each child was considered in this analysis. The results are presented as odds ratios (OR) with $95 \%$ confidence intervals $(95 \% \mathrm{CI})$ and $P$ values.

The R statistical language was used for the analyses [16].

\section{Results}

From June 2007 to May 2008, 664 specimens were collected from 592 children under six years of age with ARTI. The median age was 17.7 months (interquartile range: $9-28$ months). The female: male ratio was 1:1.3 (256/592; 43\% females). The 664 samples comprised 542 (81.5\%) nasopharyngeal swabs, 102 (15.4\%) throat swabs, and $20(3 \%)$ other respiratory samples (i.e., tracheal aspirates).

\section{Virus detection}

Overall, in $70.6 \%$ of samples, one or more viruses were confirmed with the combined results of RT-PCR and DFA. The prevalence of RSV, FluA, FluB, PIV1, PIV3, 
and AdV according to DFA was $12 \%, 0.1 \%, 0.1 \%, 1.2 \%$, $0.6 \%$, and $1 \%$, respectively. PIV2 was not detected during the study. Human coronavirus RNA was detected in 40 (6\%; 95\% CI: $4.3 \%-8.1 \%$ ) of the 664 samples, $33 / 40$ $(82.5 \%)$ in nasopharyngeal swab, $6 / 40$ (15\%) in throat swabs and $1 / 40(2.5 \%)$ in bronchoalveolar lavage. Of the 40 specimens positive for coronavirus, $21 / 40$ (52.5\%) were HKU1, 7/40 (17.5\%) were OC43, 6/40 (15\%) were 229E, and 6/40 (15\%) were NL63. All specimens were also tested with real-time RT-PCR for hRV, HBoV, and hMPV. The most common virus detected was hRV (37.6\%), followed by HBoV (20.9\%) and hMPV (11.3\%).

Most $\mathrm{HCoV}$ infections were detected in winter $(22 / 40$, $55 \%)$ and spring $(10 / 40,25 \%)$, whereas $6 / 40$ (15\%) positive samples were collected in autumn and only $2 / 40$ $(5 \%)$ in summer. The association between $\mathrm{HCoV}$ positivity and seasonality was statistically significant $(P<0.001)$. February had the highest number of $\mathrm{HCoV}$-positive specimens $(12 / 40,30 \%)$, whereas $\mathrm{HCoV}$ was not detected in June or July (Figure 1).

Of the $40 \mathrm{HCoV}$-positive samples, only 12 (30\%) were shown to involve only one virus, including 3/6 229E, 2/7 OC43, 5/21 HKU1, and 1/6 NL63. Species 229E was most frequently detected as a monoinfection (50\%), but one or more other viruses were identified in the majority (28/40, 70\%) of coronavirus-positive samples: $21 / 40$ (52.5\%) were dual infections, 6/40 (15\%) were triple infections, and four viruses were detected simultaneously in one infection (2.5\%). The viruses most frequently detected with $\mathrm{HCoV}$ were hRV (42.8\%), HBoV (32.1\%), RSV (28.6\%), hMPV (21.4\%), and AdV (3.6\%).

On average, children with $\mathrm{HCoV}$ infections were older than those negative for $\mathrm{HCoV}$ (median ages in months:
23 vs 18 months, respectively), but infection with $\mathrm{HCoV}$ and age were not significantly associated (regardless of whether age was treated as a continuous or a categorical variable; data not shown). However, age was associated with the estimated quantity of $\mathrm{HCoV}$ viral nucleic acids present (measured as $\mathrm{Ct}$ ). The association was nonlinear $(P<0.001)$ and the highest estimated viral load (lowest $\mathrm{Ct}$ ) was detected in children around 10 months old. The estimated viral load increased with age for children younger than 10 months, whereas it decreased between 10 and 24 months. The estimated shape of the association is shown in Figure 2.

\section{Clinical features}

Clinical data were available for 37 (92.5\%) of the 40 $\mathrm{HCoV}$-positive specimens and for 395/624 (63.3\%) of the $\mathrm{HCoV}$-negative specimens. The majority $(70.3 \%)$ of $\mathrm{HCoV}$-positive children were diagnosed with lower respiratory tract infections (LRTIs: bronchiolitis 56.7\%, pneumonia $13.5 \%$, bronchitis $5.4 \%$, and recurrent wheezing $8.1 \%)$. The remaining patients $(29.7 \%)$ had URTIs. Oxygen support during their hospital stay was required by $17 / 37$ (45.9\%) HCoV-positive children and the median duration was three days. The symptoms associated with $\mathrm{HCoV}$ are shown in Table 1.

The HCoV-positive children required significantly less oxygen support and had less cough, dyspnea, wheezing, LRTI, and bronchiolitis than $\mathrm{HCoV}$-negative children (Table 2; models (a)). The differences in the clinical features of the $\mathrm{HCoV}$-positive and $\mathrm{HCoV}$-negative children were very similar to those observed between $\mathrm{HCoV}$ positive children with monoinfections and $\mathrm{HCoV}$ negative children (Table 2; models (b)), indicating that

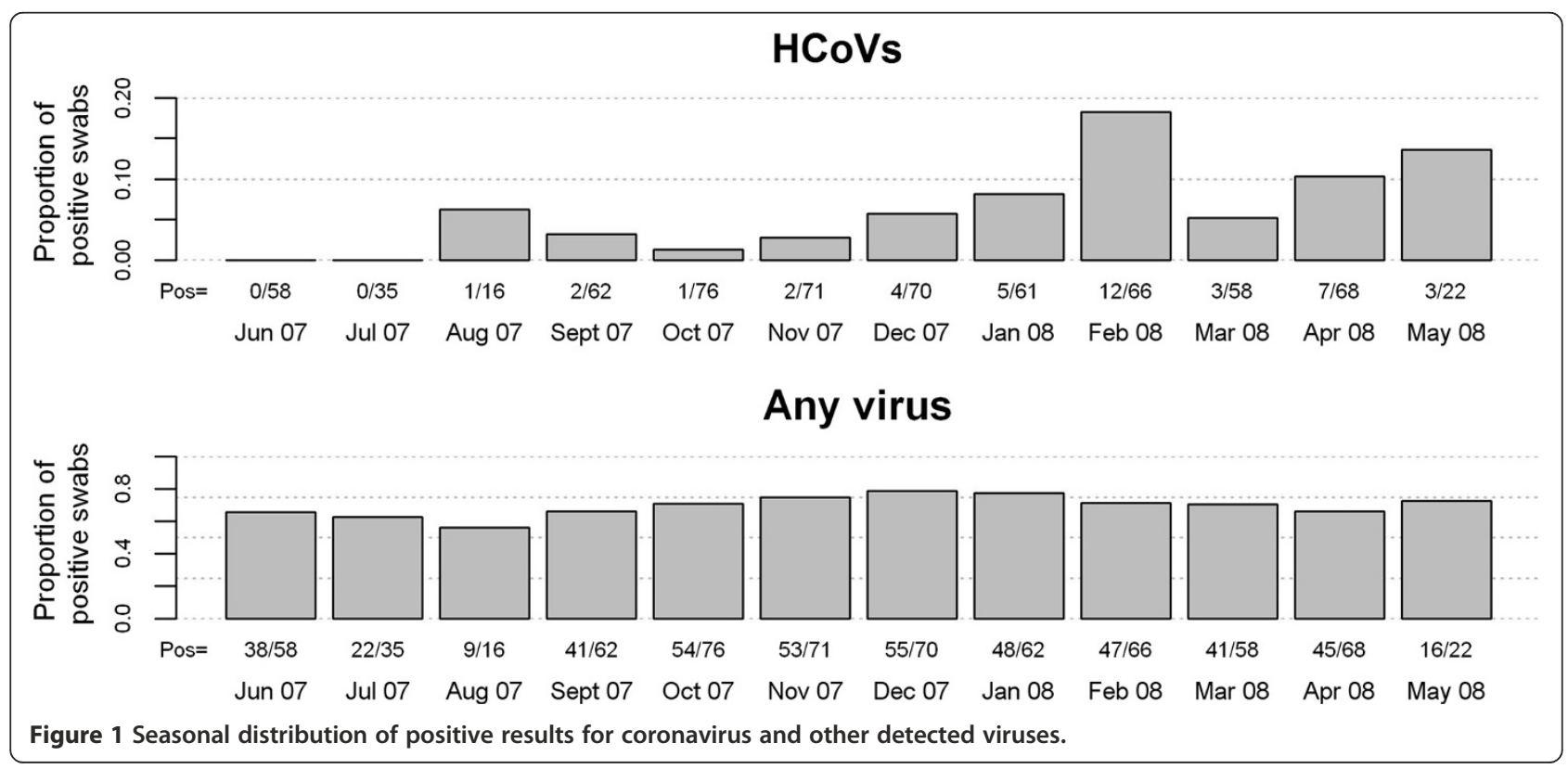




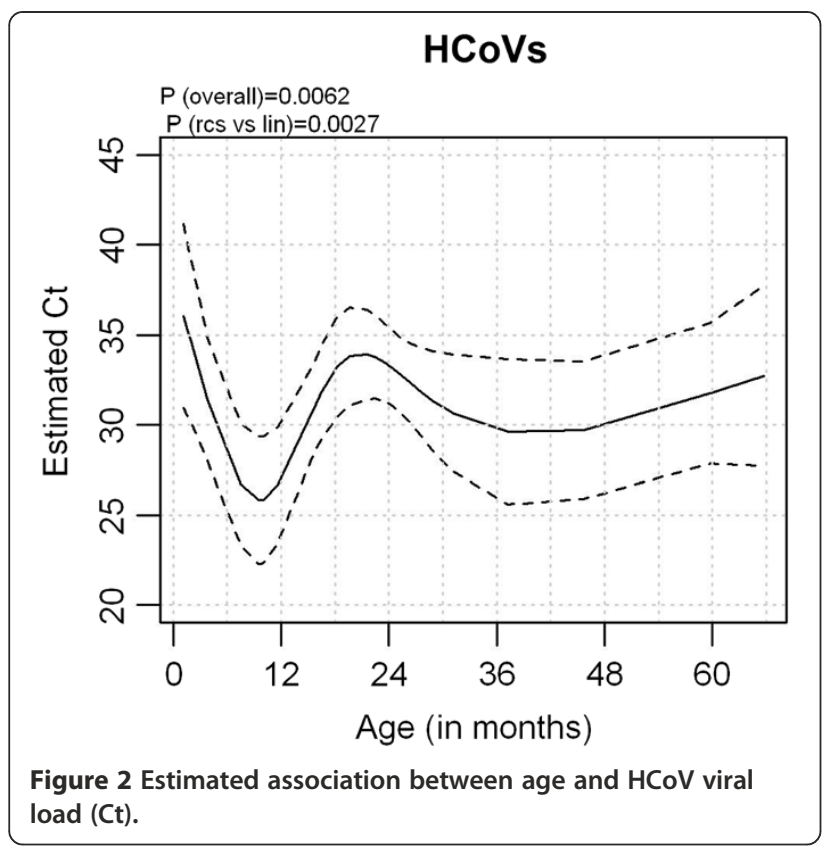

monoinfection with $\mathrm{HCoV}$ was associated with distinct clinical features. The only exception was the URTIs, which were more common among $\mathrm{HCoV}$-positive children ( $28 \%$ for $\mathrm{HCoV}$-positive children vs $5 \%$ for $\mathrm{HCoV}$ negative children). Children with $\mathrm{HCoV}$ and coinfections had URTIs significantly more frequently than $\mathrm{HCoV}-$ negative children, and less frequently than $\mathrm{HCoV}$ monoinfected children, the difference was statistically significant $(\mathrm{P}<0.001) \quad(4 / 10=40 \%$ among those with $\mathrm{HCoV}$ monoinfections, $6 / 26=23 \%$ among those with $\mathrm{HCoV}$ coinfections, and $18 / 373=5 \%$ among the $\mathrm{HCoV}-$ negative children).

An underlying medical condition was present in 11/37 (29.7\%) HCoV infected patients, whereas the other $\mathrm{HCoV}$-positive patients in this group were previously healthy. Four children with underlying disease carried $\mathrm{HCoV}$ as a single pathogen. Species 229E was more likely to be detected as a single infection than were the other viruses. Conversely, HKU1 was more likely to be detected as a coinfection with other viruses than as a monoinfection in children with an underlying medical condition. More than one virus was detected in $76.9 \%$ of $\mathrm{HCoV}$-positive children without an underlying disease or immunodeficiency. HKU1 was detected as the only viral pathogen in a nasopharyngeal swab and bronchoalveolar lavage from a 9.7-month-old child with bronchiolitis who was previously healthy.

Because the number of cases in our study was small, no comparison of all the symptoms was made with a logistic regression model, nor was a comparison of the different coronavirus species and their associations with clinical symptoms possible. No differences were found between the $C_{T}$ values of the $\mathrm{HCoV}$-positive samples according to the different clinical outcomes (data not shown).

\section{Discussion}

In our study, human coronavirus RNA was detected in $6 \%$ of respiratory samples from hospitalized children with ARTI. This prevalence was lower than we have found previously [8] and similar to that in other studies (from $2.6 \%$ to $8.7 \%$ ) [17-20]. The majority of positive samples contained the HKU1 (52.5\%) and the other coronavirus species were detected less frequently. A similar prevalence has been reported by Kuypers, and the prevalences of the $\mathrm{HCoV}$ species were reported in the same order [11]. There may be regional and annual variations in the circulation of different coronavirus species, as have been described by others [19]. HCoV was most often detected in winter and spring $(80 \%)$, with the maximum number of cases presenting in February, whereas only $20 \%$ of samples were positive for $\mathrm{HCoV}$ in autumn and summer. Coronavirus infections have also been strongly associated with seasonality in previously published studies [20-23].

The children included in our study were under six years of age (median, 17.7 months). The probability of infection with $\mathrm{HCoV}$ was not significantly associated with age. However, the $\mathrm{HCoV}$-infected patients in our study were older than those negative for $\mathrm{HCoV}$. Some studies have included populations from all age groups $[21,24,25]$, and coronaviruses have been detected in adults [26-29], young children [30-34], and neonates [35].

The association between age and the estimated viral load (from the Ct value) was interesting. The highest viral load was estimated for children about 10 months old (lower viral loads were detected in $\mathrm{HCoV}$-infected children younger or older than 10 months). One reason for the highest viral load at this age may be the presence of maternal antibodies directed to $\mathrm{HCoVs}$ in younger infants [36].

The small number of cases and high number of $\mathrm{HCoV}$ coinfections with other respiratory viruses limited our ability to determine whether specific clinical signs or symptoms were associated with coronavirus infections. We compared only group of children infected with $\mathrm{HCoV}$ and those without $\mathrm{HCoV}$ infections. In our analysis children negative to all tested viruses were not included, because there is still uncertainty about possible infection with some of the newly described viruses (which were not included in our testing array). Children infected with $\mathrm{HCoV}$ required significantly less oxygen support, and had less cough, dyspnea, wheezing, LRTI, and bronchiolitis than the HCoV-negative children. URTIs were more frequent among $\mathrm{HCoV}$-positive patients with monoinfections than among $\mathrm{HCoV}$-negative children. As 
Table 1 Demographic and clinical data for patients with and without human coronavirus infections

\begin{tabular}{|c|c|c|c|c|}
\hline & \multicolumn{2}{|c|}{ HCoV positive patients with characteristic } & \multicolumn{2}{|c|}{ HCoV negative patients with characteristic } \\
\hline & Number or median $(n=37)$ & $\%$ or range & Number or median $(n=395)$ & $\%$ or range \\
\hline Hospitalized & 37 & 100 & 395 & 100 \\
\hline Median length of stay (range) & 4 & $(2-17)$ & 4 & $(1-20)$ \\
\hline Fever & 14 & 37.8 & 112 & 28 \\
\hline Oxygen support required & 17 & 45.9 & 280 & 70.9 \\
\hline Median duration of oxygen support & 3 & $(2-14)$ & 3 & $(1-13)$ \\
\hline Cough & 23 & 62.2 & 311 & 78.7 \\
\hline Rhinorrhea & 26 & 70.3 & 233 & 59 \\
\hline Conjunctivitis & 1 & 2.7 & 16 & 4 \\
\hline Dyspnea & 16 & 43.2 & 342 & 86.6 \\
\hline Wheezing & 11 & 29.7 & 232 & 58.7 \\
\hline Vomiting & 3 & 8.1 & 25 & 6.3 \\
\hline Diarrhea & 1 & 2.7 & 7 & 1.8 \\
\hline Bronchitis & 2 & 5.4 & 9 & 2.3 \\
\hline Bronchiolitis & 21 & 56.7 & 349 & 88.3 \\
\hline Pneumonia & 5 & 13.5 & 59 & 14.9 \\
\hline Recurrent wheezing & 3 & 8.1 & 57 & 14.4 \\
\hline Asthma & 2 & 8.7 & 22 & 5.6 \\
\hline Otitis media & 1 & 2.7 & 14 & 3.5 \\
\hline Recurrent breathing/respiration difficulties & 6 & 16.2 & 106 & 26.8 \\
\hline LRTIS & 26 & 70.3 & 373 & 94.4 \\
\hline
\end{tabular}

Key: HCoV, human coronavirus; LRT/s, lower respiratory tract infections.

in other similar studies, we had only a relatively small number of coronavirus-positive samples. So far, only a few studies have included sufficient patients to permit a statistical comparison of the clinical outcomes of infections with different $\mathrm{HCoV}$ species [19,21,37]. It has recently been reported that coronavirus-infected children have LRTI less frequently than those infected with other viruses [38]. Children with coinfections had less severe disease than those with single virus infections. Children under 5 months of age had higher prevalence of single virus

Table 2 Odds ratios for the $\mathrm{HCoV}$ results according to the clinical characteristics

\begin{tabular}{|c|c|c|c|c|c|c|c|c|c|c|}
\hline & & \multirow{2}{*}{\multicolumn{3}{|c|}{$\begin{array}{l}\text { Models (a) } \\
\text { HCoV negative vs HCoV } \\
\text { positive ( } n=395 \text { vs 37) }\end{array}$}} & \multicolumn{6}{|c|}{ Models (b) } \\
\hline & & & & & \multicolumn{3}{|c|}{$\begin{array}{l}\text { HCoV positive with coinfection vs } \\
\text { HCoV positive with monoinfection } \\
\text { ( } n=26 \text { vs } 11)\end{array}$} & \multicolumn{3}{|c|}{$\begin{array}{l}\text { HCoV negative vs HCoV } \\
\text { positive with monoinfection } \\
\text { ( } n=395 \text { vs } 11 \text { ) }\end{array}$} \\
\hline & & OR & $95 \% \mathrm{Cl}$ & $P$ & OR & $95 \% \mathrm{Cl}$ & $P$ & OR & $95 \% \mathrm{Cl}$ & $P$ \\
\hline \multirow[t]{7}{*}{ Specific symptoms } & Fever & 0.76 & $0.35,1.67$ & 0.49 & 0.37 & $0.07,1.96$ & 0.24 & 0.37 & $0.09,1.51$ & 0.17 \\
\hline & Oxygen support required & 2.46 & $1.18,5.17$ & 0.02 & 7.63 & $0.99,58.61$ & 0.05 & 11.62 & $1.79,75.64$ & 0.01 \\
\hline & Cough & 2.03 & $0.93,4.41$ & 0.07 & 8.75 & $1.41,54.37$ & 0.02 & 9.43 & $1.97,45.23$ & 0.01 \\
\hline & Rhinorrhea & 0.63 & $0.28,1.40$ & 0.26 & 6.81 & $1.17,39.80$ & 0.03 & 2.36 & $0.56,9.93$ & 0.24 \\
\hline & Dyspnea & 6.85 & $3.18,14.76$ & $<0.001$ & 7.63 & $0.99,58.61$ & 0.05 & 32.26 & $4.90,213.37$ & $<0.001$ \\
\hline & Wheezing & 2.79 & $1.28,6.07$ & 0.01 & 3.28 & $0.43,25.16$ & 0.25 & 6.76 & $1.04,43.92$ & 0.05 \\
\hline & Vomiting & 0.48 & $0.14,1.61$ & 0.23 & 2.90 & $0.11,74.05$ & 0.52 & 0.99 & $0.05,21.13$ & $>0.99$ \\
\hline \multirow[t]{2}{*}{ Diagnoses } & LRTI vs URTI & 7.61 & $2.97,19.54$ & $<0.001$ & 2.62 & $0.44,15.54$ & 0.29 & 15.72 & $3.26,75.81$ & $<0.001$ \\
\hline & Bronchiolitis & 5.48 & $2.50,11.99$ & $<0.001$ & 5.72 & $0.96,33.94$ & 0.05 & 19.58 & $4.03,95.12$ & $<0.001$ \\
\hline
\end{tabular}

Key: The odds ratios and $95 \% \mathrm{Cls}$ were derived from univariate logistic regression models. In models (a): the outcome is the presence of the specific symptom, $\mathrm{HCoV}$ positivity is the covariate, and the reference category is "HCoV positive". In models (b), the outcome is the presence of the specific symptom, the covariate $\mathrm{HCoV}$ has three categories ( $\mathrm{HCOV}$ positive with a monoinfection, $\mathrm{HCoV}$ positive with coinfection, and $\mathrm{HCoV}$ negative), and the reference category is " $\mathrm{HCoV}$ positive with monoinfection". 
infections than older children [39]. In other recently published study the patients with coronavirus and influenza A virus coinfections had more severe disease than those with influenza virus infection only [40].

In the majority of our $\mathrm{HCoV}$-positive specimens (70\%), at least one other viral nucleic acid was present. To distinguish possible differences in the clinical presentations of children with a single infection from those of children with coinfections, and between the clinical presentations of infections with specific $\mathrm{HCoV}$ species, a study with more patients is required.

All $\mathrm{HCoV}$-positive children included in our study were hospitalized with ARTI: $70.3 \%$ had LRTIs and $29.7 \%$ had URTIs. Pneumonia was diagnosed in $13.5 \%$ of children and $56.7 \%$ of children had bronchiolitis; $29.7 \%$ of $\mathrm{HCoV}$ positive children had an underlying medical condition. As reported by others, single infections with $\mathrm{HCoV}$ were more often detected in children with an underlying medical condition than in previously healthy children: $5 / 11$ (45.4\%) vs 6/26 (23.1\%), respectively [11]. In children with an underlying disease, the 229E was more often detected as a single infection than as a coinfection, whereas the HKU1 was more often detected as a coinfection.

Our study also contains several limitations. Due to the retrospective nature of the study, clinical data were not available for all included patients due to the noncomprehensive or missing clinical documentation. The reasons for the missing clinical data were that children were hospitalized due to the respiratory tract infection but were not stationed in pulmonary department and were distributed to other departments of the children's hospital because of the overcrowding. For these patients the clinical records were not available to investigators. Another limitation of this study is the fact that different samples were taken in some of the patients i.e. oropharyngeal instead of nasopharyngeal swab) and this could influence the yields of coronavirus (as well as other respiratory viruses). However due to the retrospective nature of the study we couldn't influence the sampling descisions made at the clinic. The politics of sample collection in place was that nasopharyngeal swab is preferred as the optimal sample but in cases where the physical or psychological conditions of the patient would not allow for safe nasopharyngeal swab collection, the laboratory would accept the oropharyngeal swab. The samples such as tracheal aspirates or BAL samples were collected from the severly affected children. All samples originated from hospitalized patients and that can also be considered as source of selection bias. Samples from outpatients and healthy control group children would be desirable in the study to determine $\mathrm{HCoV}$ prevalence and clinical features more accurately and also to exclude the possibility that viruses are detected as "contaminants" or "normal flora". Due to the retrospective nature of the study, follow up testing was not performed. At the time of the study, detection of respiratory viruses was routinely performed by DFA instead of PCR which might underestimate the true prevalence of infections. However, we believe that these differences in sensitivity are not very prominent, especially in regard to detection of RSV virus and the fact that the study population represents young children in which DFA has best sensitivity.

\section{Conclusions}

In conclusion, we found that all four non-SARS coronavirus were detected with ARTIs in hospitalized children in Slovenia and that their identification with routine diagnostic techniques is feasible. An association between age and the viral load was found. The highest viral load was detected in children approximately 10 months of age. Further investigation of $\mathrm{HCoV}$, with the inclusion of a control group of healthy children, is required to better understand the clinical importance of $\mathrm{HCoV}$ in respiratory infections.

\section{Abbreviations}

RSV: Respiratory syncytial virus; PIV: Parainfluenza viruses; Flu: Influenza viruses; AdV: Adenoviruses; hRV: Human rhinoviruses; hMPV: Human metapneumovirus; HBoV: Human bocavirus; HCoV: Human coronaviruses; URTIs: Upper respiratory tract infections; ARTIs: Acute respiratory tract infections; LRTIs: Lower respiratory tract infections.

\section{Competing interests}

The authors declare that they have no competing interests.

This study was supported by the Slovenian Research Agency (Research Program P3-0083) and institutional department funds.

\section{Authors' contributions}

$\mathrm{MJ}$ and MP created the original idea of this research. MJ, TU, LL and MP designed the whole experiments and conducted analysis and interpretation of the data. NŽ, and UK participated in partial research work. All authors read and approved the final manuscript.

\section{Author details}

${ }^{1}$ Institute of Microbiology and Immunology, Faculty of Medicine, University of Ljubljana, Zaloška 4, Ljubljana 1000, Slovenia. ${ }^{2}$ University Children's Hospital, University Medical Centre Ljubljana, Bohoričeva 20, Ljubljana 1000, Slovenia. ${ }^{3}$ Institute of Biostatistics and Medical Informatics, Faculty of Medicine, Vrazov trg 2, Ljubljana 1104, Slovenia.

Received: 17 August 2012 Accepted: 18 December 2012 Published: 20 December 2012

\section{References}

1. Bloom B, Cohen RA, Freeman G: Summary health statistics for U.S. children: National Health Interview Survey, 2008. Vital and health. Statistics 2009, 244:1-81.

2. Shay DK, Holman RC, Newman RD, Liu LL, Stout JW, Anderson LJ: Bronchiolitis-associated hospitalizations among US children, 1980-1996. JAMA 1999, 282(15):1440-1446.

3. Mahony JB: Detection of respiratory viruses by molecular methods. Clin Microbiol Rev 2008, 21(4):716-747.

4. Cheng VC, Lau SK, Woo PC, Yuen KY: Severe acute respiratory syndrome coronavirus as an agent of emerging and reemerging infection. Clin Microbiol Rev 2007, 20(4):660-694.

5. Stewart JN, Mounir S, Talbot PJ: Human coronavirus gene expression in the brains of multiple sclerosis patients. Virology 1992, 191(1):502-505.

6. Esper F, Ou Z, Huang YT: Human coronaviruses are uncommon in patients with gastrointestinal illness. J Clin Virol 2010, 48(2):131-133. 
7. Risku M, Lappalainen S, Rasanen S, Vesikari T: Detection of human coronaviruses in children with acute gastroenteritis. J Clin Virol 2010, 48(1):27-30

8. Ursic T, Jevsnik M, Zigon N, Krivec U, Beden AB, Praprotnik M, Petrovec M: Human bocavirus and other respiratory viral infections in a 2-year cohort of hospitalized children. J Med Virol 2012, 84(1):99-108.

9. Diallo IS, Hewitson G, Wright L, Rodwell BJ, Corney BG: Detection of equine herpesvirus type 1 using a real-time polymerase chain reaction. J Virol Methods 2006, 131(1):92-98.

10. Mankoc S, Hostnik P, Grom J, Toplak I, Klobucar I, Kosec M, Barlic-Maganja D: Comparison of different molecular methods for assessment of equine arteritis virus (EAV) infection: a novel one-step MGB real-time RT-PCR assay, PCR-ELISA and classical RT-PCR for detection of highly diverse sequences of Slovenian EAV variants. J Virol Methods 2007, 146(1-2):341-354

11. Kuypers J, Martin ET, Heugel J, Wright N, Morrow R, Englund JA: Clinical disease in children associated with newly described coronavirus subtypes. Pediatrics 2007, 119(1):e70-e76.

12. Scheltinga SA, Templeton KE, Beersma MF, Claas EC: Diagnosis of human metapneumovirus and rhinovirus in patients with respiratory tract infections by an internally controlled multiplex real-time RNA PCR. J Clin Virol 2005, 33(4):306-311.

13. Maertzdorf J, Wang CK, Brown JB, Quinto JD, Chu M, De Graaf M, Van den Hoogen BG, Spaete R, Osterhaus AD, Fouchier RA: Real-time reverse transcriptase $P C R$ assay for detection of human metapneumoviruses from all known genetic lineages. Clin Microbiol Rev 2004, 42(3):981-986.

14. Lu X, Chittaganpitch M, Olsen SJ, Mackay IM, Sloots TP, Fry AM, Erdman DD: Real-time PCR assays for detection of bocavirus in human specimens. J Clin Microbiol 2006, 44(9):3231-3235.

15. Harrell FE Jr, Lee KL, Pollock BG: Regression models in clinical studies: determining relationships between predictors and response. J Natl Cancer Inst 1988, 80(15):1198-1202.

16. RdC T: R: A language and environment for statistical computing. Vienna, Austria: R Development Core Team edn; 2009.

17. Canducci F, Debiaggi M, Sampaolo M, Marinozzi MC, Berre S, Terulla C, Gargantini G, Cambieri P, Romero E, Clementi M: Two-year prospective study of single infections and co-infections by respiratory syncytial virus and viruses identified recently in infants with acute respiratory disease. J Med Virol 2008, 80(4):716-723.

18. Dominguez SR, Robinson CC, Holmes KV: Detection of four human coronaviruses in respiratory infections in children: a one-year study in Colorado. J Med Virol 2009, 81(9):1597-1604

19. Dare RK, Fry AM, Chittaganpitch M, Sawanpanyalert P, Olsen SJ, Erdman DD: Human coronavirus infections in rural Thailand: a comprehensive study using real-time reverse-transcription polymerase chain reaction assays. $J$ Infect Dis 2007, 196(9):1321-1328.

20. Leung TF, Li CY, Lam WY, Wong GW, Cheuk E, Ip M, Ng PC, Chan PK Epidemiology and clinical presentations of human coronavirus NL63 infections in hong kong children. J Clin Microbiol 2009, 47(11):3486-3492.

21. Lau SK, Woo PC, Yip CC, Tse H, Tsoi HW, Cheng VC, Lee P, Tang BS, Cheung $\mathrm{CH}$, Lee RA, et al: Coronavirus HKU1 and other coronavirus infections in Hong Kong. J Clin Microbiol 2006, 44(6):2063-2071.

22. Chiu SS, Chan KH, Chu KW, Kwan SW, Guan Y, Poon LL, Peiris JS: Human coronavirus NL63 infection and other coronavirus infections in children hospitalized with acute respiratory disease in Hong Kong, China. Clin Infect Dis 2005, 40(12):1721-1729.

23. Bastien N, Anderson K, Hart L, Van Caeseele P, Brandt K, Milley D, Hatchette T, Weiss EC, Li Y: Human coronavirus NL63 infection in Canada. J Infect Dis 2005, 191(4):503-506.

24. Arden KE, Nissen MD, Sloots TP, Mackay IM: New human coronavirus, HCoV-NL63, associated with severe lower respiratory tract disease in Australia. J Med Virol 2005, 75(3):455-462.

25. Lee BE, Robinson JL, Khurana V, Pang XL, Preiksaitis JK, Fox JD: Enhanced identification of viral and atypical bacterial pathogens in lower respiratory tract samples with nucleic acid amplification tests. J Med Virol 2006, 78(5):702-710.

26. Woo PC, Lau SK, Tsoi HW, Huang Y, Poon RW, Chu CM, Lee RA, Luk WK, Wong GK, Wong BH, et al: Clinical and molecular epidemiological features of coronavirus HKU1-associated community-acquired pneumonia. J Infect Dis 2005, 192(11):1898-1907.
27. Kistler A, Avila PC, Rouskin S, Wang D, Ward T, Yagi S, Schnurr D, Ganem D, DeRisi $J$, Boushey HA: Pan-viral screening of respiratory tract infections in adults with and without asthma reveals unexpected human coronavirus and human rhinovirus diversity. J Infect Dis 2007, 196(6):817-825.

28. Garbino J, Crespo S, Aubert JD, Rochat T, Ninet B, Deffernez C, Wunderli W, Pache JC, Soccal PM, Kaiser L: A prospective hospital-based study of the clinical impact of non-severe acute respiratory syndrome (Non-SARS)-related human coronavirus infection. Clin Infect Dis 2006, 43(8):1009-1015.

29. Brittain-Long R, Westin J, Olofsson S, Lindh M, Andersson LM: Prospective evaluation of a novel multiplex real-time PCR assay for detection of fifteen respiratory pathogens-duration of symptoms significantly affects detection rate. J Clin Virol 2010, 47(3):263-267.

30. Lambert SB, Allen KM, Druce JD, Birch CJ, Mackay IM, Carlin JB, Carapetis JR, Sloots TP, Nissen MD, Nolan TM: Community epidemiology of human metapneumovirus, human coronavirus NL63, and other respiratory viruses in healthy preschool-aged children using parent-collected specimens. Pediatrics 2007, 120(4):e929-e937.

31. Esposito S, Bosis S, Niesters HG, Tremolati E, Begliatti E, Rognoni A Tagliabue C, Principi N, Osterhaus AD: Impact of human coronavirus infections in otherwise healthy children who attended an emergency department. J Med Virol 2006, 78(12):1609-1615.

32. Fabbiani M, Terrosi C, Martorelli B, Valentini M, Bernini L, Cellesi C, Cusi MG Epidemiological and clinical study of viral respiratory tract infections in children from Italy. J Med Virol 2009, 81(4):750-756.

33. Van der Hoek L, Ihorst G, Sure K, Vabret A, Dijkman R, De Vries M, Forster J, Berkhout B, Uberla K: Burden of disease due to human coronavirus NL63 infections and periodicity of infection. J Clin Virol 2010, 48(2):104-108.

34. Pierangeli A, Gentile M, Di Marco P, Pagnotti P, Scagnolari C, Trombetti S, Lo Russo L, Tromba V, Moretti C, Midulla F, et al: Detection and typing by molecular techniques of respiratory viruses in children hospitalized for acute respiratory infection in Rome, Italy. J Med Virol 2007, 79(4):463-468.

35. Gagneur A, Dirson E, Audebert S, Vallet S, Legrand-Quillien MC, Laurent $Y$, Collet M, Sizun J, Oger E, Payan C: Materno-fetal transmission of human coronaviruses: a prospective pilot study. Eur J Clin Microbiol Infect Dis 2008, 27(9):863-866.

36. Dijkman R, Jebbink MF, Gaunt E, Rossen JW, Templeton KE, Kuijpers TW, Van der Hoek L: The dominance of human coronavirus OC43 and NL63 infections in infants. J Clin Virol 2012, 53(2):135-139.

37. Vabret A, Dina J, Gouarin S, Petitjean J, Tripey V, Brouard J, Freymuth F: Human (non-severe acute respiratory syndrome) coronavirus infections in hospitalised children in France. J Paediatr Child Health 2008 44(4):176-181.

38. Kristoffersen AW, Nordbo SA, Rognlien AG, Christensen A, Dollner H: Coronavirus causes lower respiratory tract infections less frequently than RSV in hospitalized Norwegian children. Pediatr Infect Dis J 2011, 30(4):279-283.

39. Martin ET, Kuypers J, Wald A, Englund JA: Multiple versus single virus respiratory infections: viral load and clinical disease severity in hospitalized children. Influenza Other Respi Viruses 2012, 6(1):71-77.

40. Esper FP, Spahlinger $T$, Zhou L: Rate and influence of respiratory virus co-infection on pandemic (H1N1) influenza disease. J Infect 2011, 63(4):260-266

doi:10.1186/1471-2334-12-365

Cite this article as: Jevšnik et al:: Coronavirus infections in hospitalized pediatric patients with acute respiratory tract disease. BMC Infectious Diseases 2012 12:365 